\title{
Principles and Practice of Pediatrics: JN Sharma (ed)
}

\author{
Published by Peepee Publishers and Distributors, Delhi; First Edition: 2014; \\ ISBN: 978-81-8445-135-1; Price: ₹ 930
}

\author{
Anju Aggarwal ${ }^{1}$
}

Received: 25 March 2015 / Accepted: 30 March 2015 / Published online: 14 May 2015

(C) Dr. K C Chaudhuri Foundation 2015

Of the many textbooks on pediatrics for undergraduate students, very few are written by a single author. This makes it interesting to read. This textbook covers most of the undergraduate teaching areas which a pediatric teacher would like to convey to his/ her students in simple language. It would also help any General Practitioner or Pediatric Practitioner to understand the basics especially suited to Indian needs. Postgraduates will find it useful to acquire quick knowledge about all the aspects of pediatrics when they are initiated into pediatrics and also when they want a quick revision or light reading before examinations.

The book is well written highlighting important information. Print quality is good. Most of the chapters are well written covering essential areas. Facts like methods of oxygen delivery, administration of IV fluids, causes of vomiting, photographs of helminthic infections have been covered which may not find a place in many textbooks of this level.

Chapter of cerebral palsy has been included in the chapter on growth and development which could have been shifted to the neurology section. A section on basics of genetics and dymorphology should have been included in addition to the chromosomal disorders. A chart highlighting the protein and energy content of common foods should have been included which would have made the book more complete.

It is a well written book by a single author. There are no repetitions or contradictions. It would make an interesting reading and clarify basics in pediatrics. Congratulations to the author for this venture.

Anju Aggarwal

aanju67@gmail.com

Department of Pediatrics, University College of Medical Sciences and Guru Tegh Bahadur Hospital, New Delhi 110095, India 